Article

\title{
Using Integrative Career Construction Counselling to Promote Autobiographicity and Transform Tension into Intention and Action
}

\author{
Jacobus G. Maree (D)
}

Citation: Maree, J.G. Using Integrative Career Construction Counselling to Promote

Autobiographicity and Transform Tension into Intention and Action. Educ. Sci. 2022, 12, 72. https:// doi.org/10.3390/educsci12020072 Academic Editors: James Albright and Dorothy Sisk

Received: 17 August 2021

Accepted: 20 January 2022

Published: 23 January 2022

Publisher's Note: MDPI stays neutral with regard to jurisdictional claims in published maps and institutional affiliations.

Copyright: (C) 2022 by the author. Licensee MDPI, Basel, Switzerland. This article is an open access article distributed under the terms and conditions of the Creative Commons Attribution (CC BY) license (https:// creativecommons.org/licenses/by/ $4.0 /)$.
Department of Educational Psychology, University of Pretoria, Pretoria 0001, South Africa; kobus.maree@up.ac.za

\begin{abstract}
This article reports on the use of integrative career counselling to promote autobiographical reasoning in a purposively sampled gifted 16-year-old female learner with moratorium career identity status. I implemented an explanatory, mixed-methods (QUALITATIVE-quantitative; uppercase denoting the bigger weighting given to the qualitative aspect) research design and used qualitative and quantitative career construction counselling techniques and methods and quantitative career construction counselling techniques and methods and strategies to construct data. The Maree Career Matrix (MCM) was used to gather the participant's career interests ("scores") quantitatively, and the Career Interest Profile (CIP) was used to elicit her micro-narratives ("stories") qualitatively. An adapted version of thematic data analysis was used to analyse the data. The intervention promoted the participant's (self-)reflection and reflexivity, transformed her tension into intention, led to an increase in her career options, and helped her revitalise her sense of meaning, purpose, and positivity. While the findings are encouraging, future (longitudinal) research is needed to establish the long-term influence of the intervention espoused here.
\end{abstract}

Keywords: integrative career construction counselling; gifted and talented; intervention study; moratorium career identity status; Career Interest Profile; Maree Career Matrix

\section{Introduction}

The need to respond innovatively to fundamental changes in the occupational world (including the effect of the COVID-19 pandemic) has never been greater. Factors, such as substantial job losses, increasing insecurity in the workplace, as well as disruption in educational programmes, have led to a generalised feeling of uncertainty about the future among learners. Accordingly, the need exists to help learners navigate many workrelated transitions. In the prevailing atmosphere of turmoil, people need assistance to take advantage of the changes taking place and to convert challenges into opportunities [1]. Moreover, the pandemic is changing the way we think, our dreams and our imaginations. Every crisis creates an opportunity, and it behoves us to explore the "silver linings" [2]. The COVID-19 pandemic has uncovered and increased global inequalities.

To negotiate the impact of uncertainty regarding their occupational future, and especially their future career choices, young people need to acquire the twin meta-competencies of: (i) becoming increasingly adaptable, and (ii) attaining an enhanced sense of personal and career identity [3]. Enacting these metacompetencies helps them to "address restraints that may both precede and exceed them" [4]. Above all, people's responses to change and uncertainty in the workplace should augment their career- and self-identities. If the "storyline" that runs through their career- and self-identities is clear, if they know who they are, where they are headed, why they are living and working, what life means to them, and what the sense of purpose in their career-lives is, their chances of dealing successfully with change and its impact are bolstered [5]. Career construction counselling enhances constructing the self as an internal compass that guides people in their efforts to navigate multiple transitions in their private and career environment, make meaning in their career-lives, and 
increase their sense of purpose. This notion lies at the heart of life design counselling [6]. Gifted children often express their concerns about "deep" issues, such as the meaning of life, the purpose of work, and injustice in society [7].

All of this confirms the need for the constant updating and revamping of career counselling.

\subsection{Need to Innovate Career Construction Counselling for Gifted and Talented Learners}

Since 1992, the value of drawing on one-on-one career construction counselling to help people "build" and utilise (auto-)biographical bridges to (re-)write and enact their life stories in a changing occupational world has been shown in numerous studies in countries in the Global North, especially. Researchers have demonstrated the usefulness of one-onone career construction counselling in individual contexts, especially [8,9], as well as in "matters pertaining to motivation, performance, stress, and overall life satisfaction" [10]. Little research on career construction counselling has, however, been conducted in developing countries, with only a small number of researchers showing the value of the approach in Global South contexts [11-13]. Individually and collectively, they have demonstrated how self- and career construction in life design counselling can promote career adaptability and sound career choice decision making in (South) Africa, especially in group contexts. As indicated in earlier publications, very few people in Global South countries can afford expensive one-on-one assessments [14].

Given the variety and magnitude of the changes in the world of work globally, many learners today are experiencing career decision-making difficulties, including gifted and talented learners. Some people believe that these learners do not require career counselling because they generally know automatically what careers they want to venture into [15]. However, ample evidence suggests that this is often not the case.

\subsection{Decision-Making Difficulties of Gifted Learners}

The following four challenges impact most career choice decisions [16]: (i) dealing with the need to compromise in career-decision making; (ii) accepting a satisfying course of action; (iii) managing indecision and uncertainty; and (iv) considering people's conscious and as well as subconscious career decision-making processes. More than ever before, there is today ongoing speculation about the uncertain future of work, the large number of "traditional" jobs that are disappearing, and the possibility of robots and artificial intelligence taking over people's jobs. School learners especially lack the knowledge and preparation needed to make appropriate career choices, and are thus calling on career counsellors to rethink their counselling praxis in this regard.

Researchers have listed five different kinds of career decision challenges to help career counsellors to: (i) explain and (ii) plan interventions to deal with such challenges. These are:

i. inadequate career choice information;

ii. inadequate sense of career and self-identity;

iii. un- or underdeveloped career decision-making capacity;

iv. anxiety about choosing a career;

v. incongruity between people's views and significant others' views regarding their career choices $[17,18]$.

Here, four career identity statuses or styles young people use to contend with age and life phase-related identity issues have been identified [19]. These statuses range from high to low: (i) commitment (to work roles) and (ii) exploration (of the nature of work roles) [20]. The four statuses are:

a. identity achievement (high commitment and exploration);

b. foreclosure (high commitment but low exploration);

c. identity diffusion (low commitment and exploration); and

d. moratorium (low commitment but high exploration).

This current article focuses on moratorium identity status. For the reasons spelled out above, I have drawn on career construction counselling in all my research-related 
endeavours to understand vocational and career behaviour intervention strategies fully and to help people write their idiosyncratic life stories and subsequently execute or enact these stories.

\section{Theoretical Framework: Career Construction Theory (CCT)}

Savickas' career construction theory (CCT) was used in this study as the theoretical framework for constructing (gathering), analysing, and interpreting data. CCT is predicated on the belief that people construct their careers by making meaning in and through their careers and using their careers to integrate themselves into society and make social contributions [21]. CCT merges personal (private) meanings relating to earlier memories, present experiences, and future intentions into ever-evolving, key life themes [22]. It advances the idea that the subjective career can promote critical (self-)reflection and biographical reflexivity or metacommunication, uncovered through conversation and implemented through work behaviour [23].

I chose CCT as my theoretical and conceptual framework as career construction can help people to articulate their life stories (autobiographies). These micro-stories can then be unpacked (deconstructed), clarified, revised, and interwoven (reconstructed) by counsellors and their clients (co-constructed) to enhance clients' sense of meaning, purpose, and hope in their lives. Career construction counselling thus reinforces clients' self-construction [5]. Accordingly, clients learn to accept ongoing change in the workplace and also in their private lives as the 'new normal'. From this perspective, accepting and even welcoming change can help to realise the twin aims of choosing and constructing careers and designing successful lives. These two aims are achieved by eliciting people's micro-life stories and merging them into an intelligible, grand, macro-life story filled with meaning and hope $[8,24]$.

Tailoring career theories to meet the distinctive needs of gifted people can facilitate understanding the particular needs of this population [25]. The following section should be read in this light.

Some key dimensions of career construction counselling are discussed briefly below.

\subsection{Key Dimensions of Career Construction Counselling}

People increasingly have to design themselves and choose and construct careers in 'post-traditional' societies [6]. Work environments are becoming more uncertain. Staying with corporations for a lifetime and retiring with sufficient funds to see them through for the rest of their days is becoming a thing of the past. As a result, many people now have to construct their career-life trajectories by recognizing and addressing opportunities and restrictions in their career-life identities and social contexts. A "decent" income is no longer guaranteed, thereby undermining people's emotional-social, psychological, and physical wellbeing. To remain relevant and valuable in these new circumstances, career counsellors need to help people attain the meta-competencies of (career) adaptability and a good sense of identity [26]. These competencies should enable people to deal with real or perceived limitations or barriers and help them to create the circumstances needed to improve their chances to transcend such challenges and barriers successfully.

It is therefore clear that the future of the career counselling profession depends on the ability of career counselling researchers, practitioners, and policy-makers to design innovative models and strategies to enable their clients to manage an increasingly less predictable, less regulated, and less stable work environment. Clients have to be helped to fit their work into their lives, rather than their lives into their work.

\subsubsection{Narratability}

This word refers to people's coherent narrating or recounting of their career-life stories. People's micro-life stories are unique texts articulated by people and then read back to them by career counsellors [27]. By not only hearing but actually listening carefully to themselves, their "advice" to themselves becomes manifest; accurate advice comes only 
from within [28]. Career counsellors need to facilitate a safe or "sacred" space or holding environment for people to recount their micro-stories in an atmosphere of reciprocal trust and respect. This enhances the breadth and depth of the career counsellor-client working alliance and encourages people to share their "deepest secrets" (content or stories they will not otherwise share with others) with their counsellors $[29,30]$. The telling of micro-stories (petit récites) enables people's key life themes to surface and facilitates the subsequent connecting of their conscious knowledge about themselves with their subconscious insights into their innermost desires and strivings. In a sense, narratability relates to the issue of "languaging", which is the negotiation and production of meaningful outcomes. Stated differently, it refers to meaning-making and knowledge-shaping and enhancing experiences through language [31].

\subsubsection{Autobiographicity}

This term refers to people's ability to turn to their autobiographies (life stories) when they face transitions in their career-lives. People draw on their autobiographies (autobiographicity) to provide themselves with a proven strategy and advice on managing current and future transitions in their workplace.

Acceptance of the value of subjective (qualitative) career counselling theory and interventions has grown markedly since 1990. Today, qualitative and quantitative approaches are widely recognised as equally important in career counselling [14].

\subsubsection{Integrative QUALITATIVE-Quantitative Career Counselling}

The integrative QUALITATIVE-quantitative (uppercase denoting the more significant weighting given to the qualitative aspect) approach discussed in this article blends people's "subjective stories" (qualitative data) with their "objective" test scores (quantitative information). The approach thus includes considering both subjective and objective aspects of individuals' personality configurations during the career counselling and decision-making process. Many career counsellors emphasise drawing on people's sense of self and individuality rather than on their sense of similarity and on eliciting people's career-life themes rather than their interest patterns. In addition, greater emphasis is placed on interventions that promote not only intentionality (the intention to take specific actions) and on action and forward movement (turning tension into intention and into actual action) [3,6]. The approach has gained increased acknowledgement globally [14,26,32].

From the perspective of the current article, there is a great need for research on career counselling for gifted and talented people in particular. In my and others' view, learners who show promise in science, technology, engineering, and mathematics (STEM) subjects tend to be nudged towards following STEM-related fields of study and associated careers-without due consideration of the importance of "other" (subjective) factors in co-determining which fields of study they should follow [33]. This is a seriously underresearched topic. This silence in the literature is difficult to understand [34]. Whereas career construction counselling enhances the autobiographical author facet of the psychological self (PS) primarily, it also talks to the social actor and the motivated agent as critical facets of the PS. It shows how the three notions (social actorship, motivated agency, and autobiographical authorship) can be blended to bolster the construction, deconstruction, co-construction, and reconstruction of individuals' "grand" (career-)life stories [35].

\subsection{Goals of the Study}

For the reasons spelled out above, and my awareness that many gifted and talented learners struggle to deal with constructs such as the "deeper" meaning of their lives and the idea of having a "calling" for specific careers [36], I set out to determine the value of integrative QUALITATIVE-quantitative career counselling for a purposively selected gifted 16-year-old female learner with moratorium career-identity status. However, I did not attempt to compare the effectiveness of this intervention with other interventions in this regard. The following specific research questions were addressed: 
a. What was the effect of the intervention on the participant's sense of career identity?

b. What was the effect of the intervention on the participant's moratorium careeridentity status?

\section{Materials and Methods}

\subsection{Participant and Context}

The participant (Ashleigh, a pseudonym; a learner described as "gifted" by the school counselling team) was a purposely selected 16-year-old, white English-speaking young woman in Grade 11 from a higher socio-economic environment. Ashleigh (who attended a private school) approached me during the second part of 2020 for career counselling. She felt unsure about which fields of study and careers she should consider: "Teachers tell me I have the potential to become 'anything'. I would like to know what career options would suit me as a person, my ambition to travel and make a difference through my work, and my desire to make money, too. Give me all scope of possible careers I may pursue; even occupations I have not considered before. I want to be firm in my assurance of what field I am best suited for and thus be able to apply securely next year for 'varsity'." Ashleigh and her parents agreed that an integrative QUALITATIVE-quantitative career counselling intervention should be implemented; in other words, a qualitative and quantitative assessment was conducted. The outcomes (stories and scores) were later interpreted integratively (i.e., the qualitative and quantitative information were blended) to facilitate career construction. (The parents requested the inclusion of aptitude tests, to which Ashleigh agreed.)

\subsection{Data-Gathering Instrument}

\subsubsection{Quantitative Data-Gathering}

The Maree Career Matrix (MCM) [37] draws on (a) trait-and-factor theory [38], (b) developmental theory [39], and (c) social learning theory [40]. Developed in South Africa between 2002 and 2015, the MCM measures interests and self-estimates of confidence to follow specific careers. The psychometric properties of the MCM are considered good [37]. Scores on the MCM provide career counsellors and their clients with a starting point for clarifying and discussing career profiles in greater depth.

The Senior Aptitude Tests (Advanced) (SAT-L) has 10 subscales, namely, vocabulary, verbal reasoning, nonverbal reasoning, calculations, reading comprehension, comparison, price controlling, 3-D spatial visualisation, mechanical insight, and memory. Developed and standardised by the Human Sciences Research Council (HSRC), the SAT-L has good psychometric properties in terms of test reliability and construct validity [41].

\subsubsection{Qualitative Data-Gathering}

The Career Interest Profile (CIP, Version 6) can be used to construct qualitative data [42]. It is grounded in career construction theory and reflects the differential, developmental, and narrative traditions. It comprises four parts and contains several purposefully structured questions. In Part 1, assessees are asked to provide biographical details and family influences. In Part 2, assessees respond to career choice questions (e.g., "Which three specific careers would you like most and which three the least? Give the single most important reason why this is the case"). In Part 3, assessees answer questions on their career category preferences and dislikes. Lastly, in Part 4, assessees respond to 14 micro-life story questions.

The small quantitative part of the CIP (Part 2) has good psychometric properties [43].

Both the CIP and the MCM can be administered on an individual or group basis. Whereas I scored the two tests, an external coder with many years of experience in the field coded the qualitative data to enhance the trustworthiness of the process. Ashleigh was also asked to write an autobiographical narrative entitled "My life story" and bring it with her on the day of the intervention. 


\subsection{Design and Procedure}

\subsubsection{Mode of Inquiry}

An integrative QUALITATIVE-quantitative approach to career counselling was implemented and an explorative, single, descriptive, instrumental case study design was used in a one-on-one research setting. Moreover, the inquiry was naturalistic and located in an interpretive paradigm.

\subsubsection{Procedure}

Ashleigh and her parents asked the counsellor to conclude the intervention and feedback on the same day (four and a half hours, including several breaks). In Session 1 (the initial assessment lasted for two and a half hours, including several breaks), Ashleigh's career-life story was elicited (she completed the Career Interest Profile (CIP) while I interviewed her parents). The Maree Career Matrix was then administered, followed by the Senior Aptitude Tests. The outcomes were integrated after the assessment. Session 2 (authorisation-60 $\mathrm{min}$ ) was devoted to the 'validation' of Ashleigh's story. After she and I had clarified and integrated the assessment outcomes, in Session 3 (facilitating forward movement $-60 \mathrm{~min}$ ), a feedback interview was held with Ashleigh and her parents. The session ended with a discussion of how action and forward movement could be planned and executed. We discussed the general, psychosocial, psychoeducational, and career choice information I had provided. The interview included a discussion of Ashleigh's key life themes (uncovered by her earliest recollections and her responses to questions about the most significant challenges she had faced early in life) [44]. I stressed that Ashleigh knew herself better than anyone else, that only she could advise herself, and that she should follow her own advice. Each time she asked for advice, I read her own words (responses) back to her and requested her to reflect carefully on what she had said. Throughout the assessment, she was reminded that her (perceived) areas or opportunities for development and growth could be converted into strengths and that any "pain" she had experienced could be converted into hope and social contribution.

Rigour of the Study: Enhancing Credibility and Trustworthiness

A chain of evidence was provided based on constant comparison methods [45] that bolstered trustworthiness and credibility. I also drew on crystallisation to promote the study's validity by asking different qualitative questions [46,47]. Crystallisation gives researchers a better grasp of a research topic. Peer debriefing was facilitated by discussing the outcomes and inferences with a knowledgeable colleague. Peer validation was achieved by repeatedly requesting Ashleigh to reflect on and review all matters related to the research at all stages. I also asked her to 'authorise' (validate or confirm) my interpretation of her responses or, when she disagreed with my interpretation, to de-authorise my interpretation. (Ashleigh was asked to reflect on her answers to questions and the career counsellor's interpretations on several occasions.) She was assessed in English (her mother tongue). Triangulation was achieved by implementing qualitative and quantitative assessments and interventions.

\subsection{Data Analysis}

\subsubsection{Qualitative Data}

Ashleigh's comments and the "reflective conversations" or dialogues between Ashleigh and me were audiotaped and transcribed verbatim. I then used an adapted version of thematic analysis [48] to allow themes and subthemes to emerge from the data obtained from the open-ended questions of the CIP. In addition, I drew on consensual qualitative research (CQR) to facilitate achievement of consensus decisions [49]. All findings were carefully checked against original data for purposes of verification. Specific actions that promoted sound data analysis are listed below [6]:

a. Asking Ashleigh what her responses to questions about, for instance, her role models meant to her; 
b. Carefully noting repeated words and expressions;

c. Reading Ashleigh's words and expressions to her and clarifying their meaning. Ashleigh was also asked to say certain words and phrases out loud (to promote the authenticity of the experience);

d. Her responses to the three earliest recollections question and the CIP questions about her greatest challenges when she was young were analysed to reveal her central career-life themes, relating these themes to possible fields of study (co-construction).

\subsubsection{Quantitative Data}

I drew on the quantitative inventories' results to identify interest patterns (themes and subthemes). Identified patterns were clarified with Ashleigh to establish how well (or not) they aligned with her perceptions of her interest configuration profile. We then triangulated interest patterns with the CIP interest patterns.

\subsubsection{Integrating Qualitative and Quantitative Outcomes}

Qualitative as well as quantitative data were gathered to allow both data types and their associated designs to add to the richness of the research findings and to indicate (or not indicate) their complementarity [50]. Triangulating findings can help researchers uncover data for further analysis and resolve areas of disagreement, thereby yielding more profound insight into the phenomenon under investigation than unconnected analyses. Moreover, whereas quantitative information ("scores") can uncover objective data (participants" "conscious" knowledge about themselves), a qualitative approach can elicit participants" "stories" and uncover subjective data (participants' "subconscious" knowledge about themselves) that can facilitate the identification of their key life themes. Ashleigh's responses to the CIP questions (together with her meta-reflections on these responses) clarified her interests and personality traits, her career preferences, her key life themes, and how meaning-making manifested in her life. The responses also shed light on her sense of purpose and hope [6]. We integrated and used the integrated data (co-construction) to identify fields of study that would help her "find a job", improve her employability, and give her a sense of hope and purpose in her life.

\subsection{Ethical Issues}

The research was approved by the University of Pretoria's Institutional Review Board (ethical clearance number: UP 06/09/03). I obtained written informed assent and consent from Ashleigh and her parents for the research's analysis and (anonymous) reporting. To differentiate my roles of researcher and practitioner [51], I carefully planned the different facets of my dual roles. I maintained an open relationship with Ashleigh, discussed all aspects of the intervention with her, and explained in detail the questionnaires used [52]. Lastly, I remained aware that Ashleigh's wish to "please" me may (either consciously or subconsciously) have affected what she told me, and, to obviate this, I clarified all of her responses with her [53].

\section{Findings}

\subsection{Quantitative Outcomes}

a. The $S A T(L)$ : The exceptional results obtained in these aptitude tests confirmed Ashleigh's giftedness and were in line with her outstanding academic achievements as well as the comments of her teachers and parents.

b. According to the MCM, Ashleigh's highest preferred interest and confidence categories were medical and paramedical services, research, word artistry, and musical.

\subsection{Qualitative Outcomes}

Ashleigh's preferred interest categories corresponded strongly positively with her quantitative outcomes: 
1. Medical and paramedical services; 2. research; 3. word artistry; 4 . musical; 5. adventure, plants and animals and the environment; 6 . legal practice and security services; and 7. executive and management practice.

Only selected responses to questions in the last part of the CIP are discussed below. The numbers given here do not reflect the actual numbers in the CIP.

1. "How can I be of value, use, or help to you?" [8].

"I was told that I have the potential to become 'anything' but I am not sure what to study. I want to know (and be firm in my assurance of) what career options would suit me best as a person, address my ambition to travel and make a difference through my work, and help me make money, too. My parents and I do not agree $100 \%$ on what I should study" (Ashleigh's responses are verbatim with only light editing to preserve their authenticity.) (She gives clear evidence of career confidence, concern, and curiosity.)

\section{2. "What are your greatest strengths?"}

"I am intelligent, loyal, determined, strong-willed, confident, honest, and a seeker of knowledge."

Areas for growth?

"I am impatient, prefer logic over sympathy, can be quite serious and reserved, am overly indecisive, can be too cautious and mistrusting, am an anxious over-thinker, and am very highly strung."

3. "Whom did you admire or who were your role models when you were young? Why?"

"Jesus Christ because He lived the perfect life and sacrificed His life to save the world. I admire His love, faith, compassion, and goodness."

"Jeremy Camp. He is a Christian singer who lost his wife to cancer. I look up to him as he suffered a lot, yet he only grew in his faith and never gave up. He still believes despite the tribulations he faced."

"Bethany Hamilton. She is a Hawaiian surfer who lost her arm to a shark attack when she was 13 years old. I admire her for her motivation and hard work despite the loss of her arm. She is still a professional surfer and she never gave up despite the suffering. She is now happily married and has started a family too." (Many of the traits listed here are "typical" of gifted learners' traits in general [54].)

4. “What are your favourite quotations?" (Ashleigh's advice to herself.)

"Live life to the fullest."

"Rather regret having done something than not having done it at all."

"Let go and let God."

5. The three things that hurt me most when I was young and that I do not want others to suffer: "First, being bullied and being injured physically (and emotionally) by friends. Second, being forced into challenging activities that I could not yet do and so felt inferior or got injured. Third, trying to fit in amongst those of my age, as I preferred the company of older children or adults."

These responses are consistent with those elicited from her three earliest recollections (see below). Recurring themes included: (i) her hatred of being bullied; (ii) her being misunderstood; (iii) her realisation that well-meaning people sometimes have unrealistic expectations about (significant) others; (iv) her realisation that trying to meet such expectations could have serious negative consequences and hurt deeply; and (v) her realisation and acceptance that being "different" and somewhat "smarter" than others could result in isolation from her peer group.

6. Ashleigh's earliest recollections.

Brave new "friend" comforts distraught toddler.

a. " At the age of two, my parents and I flew to London. A week before our departure, I lost my best friend. She no longer wanted to be my friend because 
she believed I was 'different'. I felt sad and reluctant to travel to London. On our second day in London, walking around in the city, we discovered a 'toy shop'. My parents took me inside and bought me a gift. I chose a Spiderman doll (to me, Spiderman was brave and selfless and possessed extraordinary power). Finding a replacement for my best friend relieved the sense of loss I was experiencing after I had lost my first Spiderman and then my close friend. (SMILES) Travelling to London turned out to be a rewarding experience despite my initial reluctance to travel there."

(Feelings associated with this recollection: a sense of rejection and loss but also of subsequent healing.)

Painful accident embarrasses curious, committed young girl.

b. "When I was seven years old, our class went on an adventure camp. I was curious to learn more about nature, animals, and the like and had looked forward very much to the experience. That evening, we were told to shower (quickly, because there were many of us but thoroughly). I did my best to follow the teacher's instructions but somehow slipped in the shower and cracked my scapula. I was in a great deal of pain and discomfort. I recall the entire bathroom group staring at me sobbing. I felt like a baby; very ashamed and incompetent. I was only trying my best to shower as fast as possible to make sure that I would not be late for supper."

(Feelings associated with this recollection: rejection, pain, humiliation, embarrassment, and disappointment.)

Unreasonable teacher chastises innocent little girl.

c. " At the age of six, at the end of my first day at school, we were waiting inside the classroom for our parents to fetch us. I was very keen to see my mother to share what had happened on my first day at school with her. I looked at the schoolyard intently through a window while the other children were playing and talking. When I saw my mother stop outside the school ground, get out, and walk towards our classroom, I quickly took my little backpack and tried to rush outside. However, our teacher shouted at me, told me to stop, sit down, and wait inside until my mother had arrived outside our classroom. I felt embarrassed because I didn't and still don't need anyone to reprimand me or shout at me."

(Feelings associated with this recollection: excitement, humiliation, treated unjustly, and disappointment.)

(Co-constructing her career-life story.)

\section{Key Career-Life Themes}

Ashleigh's central life themes were identified by scrutinizing the qualitative "data" (outcomes). The first recollection sets the backdrop for her life story. Having lost her favourite toy and her best friend, she felt insecure, disappointed, rejected, and afraid to fly to a foreign environment. Gifted people often experience feelings of not being accepted [55]. Visiting London co-shaped Ashleigh's life story. Having overcome her initial reluctance to fly, she discovered a brave new "friend" in the foreign environment (London). The new "friend" helped her deal with the pain of rejection. She realised the value of being brave and willing to dare (a key life theme).

Ashleigh's first verb is "travel". This action corroborates the theme conveyed by the second and third earliest recollections, namely her realisation that life is not fair and that being bold, courageous (she was initially unwilling and afraid to travel to a distant, foreign destination), and self-sufficient (self-aware and reliant) is of key importance in life. Likewise, she realised that paying too much attention to the hurtful or inappropriate actions of others served little purpose. 
A careful perusal of the second and third recollections uncovered her keen sense of curiosity (a common trait of gifted children), her disappointment at having been embarrassed and treated unfairly, and her deep sense of commitment to tasks at hand. (The overlap between the themes that emerged from Ashleigh's responses to Questions 4 and 5 is clear.)

Lastly, I asked Ashleigh how she had experienced the intervention.

a. "What did you enjoy?"

"Seeing what I can achieve, my interests, and understanding myself and my deeperseated 'strivings' better." (Reflexivity)

b. "What did you not enjoy?"

"Nothing really, but I was keen to shorten breaks between assessments."

c. "Is there anything else that I need to know about you?"

Asked if she had any further comments, she smiled and said: "Despite being serious and highly organised, I love adventure-related activities, trying out new things, and travelling." (This response confirms the key themes that had emerged from her earliest recollections and most significant challenges faced.)

Ashleigh and I discussed her responses to the CIP questions in depth. I pointed out the "unobvious" meaning of responses such as her responses to the question about role models "who portray tentative solutions to their main problems and dominant preoccupations" p. 170). The role models represented only possible solutions to her central life problems. Her repeated reflections revealed her personality traits, career preferences, central life themes, and purpose. Ashleigh and I jointly drew on the information (co-construction) to identify several possible fields of study and possible careers that would instil a sense of purpose in her life, give meaning to her work, and help her make meaningful social contributions. Ashleigh reflected carefully on the correspondence between the quantitative and qualitative outcomes (triangulation). Together, we used repeated words and phrases to help us identify themes and subthemes in the data.

Ashleigh and I drew up a table in which we placed the qualitative outcomes (the many "micro-stories") alongside the "results" ("scores"). I repeatedly asked Ashleigh to reflect on the correspondence between the "stories" and the "scores" to facilitate triangulation of the two data sets, which revealed a positive correlation between the two sets. Her "scores" helped her confirm several fields of study and associated careers for possible job analysis. Still, they did not add significantly to the study fields already identified through her "micro-stories".

Medicine

Dietetics

BSc (Biological Sciences, e.g., Biochemistry, Biotechnology, Food Science, and Microbiology)

BSc (Genetics)

BVSc (Veterinary Science)

BSc (Actuarial Sciences / Actuarial and Financial Sciences)

BA (Languages/Journalism)

BCom (Law)

Gifted learners should be exposed to a broad range of careers and associated fields of study. I recommended that Ashleigh examine a broader spectrum of careers than she had considered thus far in her life. In addition, I told her that she had the potential to reach the top at any academic institution, which would help her to realise her dream to travel the world, receive acclaim in her field of work, and (in Ashleigh's own words) "do something meaningful by expanding current knowledge in my field of study and make a difference in the lives of others". 


\section{Discussion}

The goal of this study was to examine the value of integrative QUALITATIVEquantitative career construction counselling for a gifted 16-year-old female learner with moratorium career-identity status. I addressed the following specific questions.

a. What was the effect of the intervention on the participant's sense of career identity?

b. What was the effect of the intervention on the participant's moratorium careeridentity status? Below, I discuss two questions and briefly relate the research findings and the literature on the topic.

\subsection{What Was the Effect of the Intervention on the Participant's Sense of Career Identity?}

People's career identities deepen their experience of meaning and purpose in their lives [56]. The findings in this study support this view. After the intervention, the participant (Ashleigh) displayed an enhanced sense of career identity. She also realised that as much as she loved and respected her parents and their advice, she should instead enrol in a course that would more likely better meet her idiosyncratic career-choice needs. She showed a good understanding of how she could enact her key life themes and unique patterns of personal meaning in her work. In other words, she acquired an enhanced understanding of not only what she wanted to do in her 'job' but why she believed her job or career would help her actualise her authentic career identity by enabling her to "address [her] ambition to travel and make a difference through [her] work, and help [her] make money, too" [36]. Articulating her life story helped her use her autobiography for guidance (advice) concerning her career identity about possible future career decisions.

\subsection{Acquiring a Sense of Purpose and Meaning}

The findings in this research also support the view that addressing people's need to experience a sense of purpose and meaning in their career-lives is a prerequisite for their understanding the connection between their life purpose intentions and their actual careerrelated choices [57]. The participant's tension resulting from the incongruence between her parents' career choices for her and her own choices led her to seek greater clarity on the issue. She realised that choosing a career entailed more than merely finding an outlet for her interests and other personality traits but, instead, enacting her key life themes. Understanding that her future career could help her provide a holding environment for people who had experienced similar challenges prompted her to actualise her careerchoice ideals. I reminded her that job analysis was essential and should not be taken lightly. A thorough job analysis would help her identify valuable educational and career opportunities [58]. The participant later completed a comprehensive work analysis, which strengthened her resolve to become a medical doctor and actualise her talents and make a difference in the lives of others.

\subsection{What Was the Effect of the Intervention on the Participant's Moratorium Career-Identity Status?}

The intervention reported on in this article helped the counsellor and the participant explore the roots of the participant's moratorium career-identity status. It highlighted the importance of listening carefully to the participant and allowing her to be in control of her career-choice decisions [7]. Consistent with the findings of earlier studies [59], the present research revealed the inseparability of career and personal counselling $[60,61]$. The study also confirmed the view that career counsellors should first endeavour to link gifted learners' reasons for requesting career counselling with their overall search for meaning and purposefulness. It testified to the usefulness of the career counselling style (using the $C I P$ in conjunction with the $M C M$ ) in eliciting various micro-life stories of a young woman with moratorium career-identity status. 


\subsection{Limitations}

Longitudinal research in diverse contexts is essential to confirm the value of the intervention in different (individual and group) settings. The participant's eagerness to seek career counselling and satisfaction with the approach may have influenced how the participant experienced the intervention. In addition, my personal convictions, my distinctive style, and my bias towards people from minority groups (including gifted people) may have influenced the success of the career counselling intervention described here. Lastly, the participant's unique contexts are not typical of the contexts of most gifted young women in (South) Africa.

\section{Conclusions}

This article shows that the career counselling approach described here helped a gifted young woman with moratorium career-identity status deal satisfactorily with career decision-making challenges and helped her turn tension into intention and action [1,3]. It also highlights the importance of linking gifted learners' rationale for seeking career counselling with their more profound quest for meaning and purposefulness. The intervention style discussed here can increase our insight into the impact of such an integrative QUALITATIVE-quantitative approach to career counselling on gifted learners. Such an approach may well limit the loss of many thousands of gifted and talented learners so badly needed to help solve the significant challenges the world is facing today. Such efforts can help gifted learners escape the trap in which they often find themselves [62]. It can also promote their sense of achieving symbolic immortality (leaving a timeless legacy and making a timeless contribution to humankind) [63-65].

Funding: This research received no external funding.

Institutional Review Board Statement: The study was conducted in accordance with the Declaration of Helsinki, and approved by the Ethics Committee) of the faculty of education, University of Pretoria. Protocol code UP 06/09/03; 3 November 2021.

Informed Consent Statement: Informed consent was obtained from the participant involved in the study.

Data Availability Statement: The data presented in this study are available on request from the corresponding author. The data are not publicly available due to South African POPI Act requirements.

Acknowledgments: I thank the participant for taking part in the research. I thank Tim Steward for his editing of the text. No financial support was received for the research.

Conflicts of Interest: The author declares no conflict of interest.

\section{References}

1. Savickas, M.L. Career construction theory and counseling model. In Career Development and Counseling: Putting Theory and Research into Work, 3rd ed.; Lent, R.W., Brown, S.D., Eds.; Wiley: New York, NY, USA, 2020; pp. 165-200.

2. Goldin, I. COVID-19 Has Shown That Following the Same Road will Lead the World over a Precipice. 2021. Available online: https: / / www.outlookindia.com/newsscroll/covid19-has-shown-that-following-the-same-road-will-lead-the-worldover-a-precipice/2093773 (accessed on 18 June 2021).

3. Savickas, M.L. Theories of Psychotherapy Series. Career Counseling, 2nd ed.; American Psychological Association: New York, NY, USA, 2019.

4. Savickas, M.L.; Savickas, S. A history of career counselling. In International Handbook of Career Guidance, 2nd ed.; Athanasou, J.A., Perera, H.N., Eds.; Springer: Berlin/Heidelberg, Germany, 2019; pp. 25-44.

5. Guichard, J. Self-constructing. J. Vocat. Behav. 2009, 75, 251-258. [CrossRef]

6. Savickas, M.L. Career Construction Theory: Life Portraits of Attachment, Adaptability, and Identity; M. L. Savickas: Rootstown, OH, USA, 2019.

7. Silverman, L.K. Honoring the precious uniqueness of your gifted child. Gift. Educ. Internat. 2021, 37, 67-79. [CrossRef]

8. Del Corso, J.; Rehfuss, M.C.; Glavin, K. Striving to adapt: Addressing Adler's work task in the 21st century. J. Individ. Psychol. 2011, 67, 88-106.

9. Taber, B.J.; Briddick, W.C. Adlerian based career counseling in the age of Protean Careers. J. Individ. Psychol. 2011, 67, 107-121. [CrossRef] 
10. Klehe, U.-C.; Fasbender, U.; Van der Horst, A. Going full circle: Integrating research on career adaptation and proactivity. J. Vocat. Behav. 2021, 126, 103526. [CrossRef]

11. Maree, J.G. Life design counselling. In Career Psychology, 3rd ed.; Stead, G., Watson, M., Eds.; Van Schaik: Pretoria, SA, USA, 2017; pp. 105-118.

12. Maree, J.G.; Gerryts, E.; Fletcher, L.; Jordaan, J. Using career counselling with life design principles to improve the employability of disadvantaged young adult. J. Psychol. Afr. 2019, 29, 110-120. [CrossRef]

13. Sethlare, R.; Wood, L.; Meyer, L. Exploring Group Life Design with teachers in the context of poverty related psychosocial challenges. S. Afr. J. Educ. 2017, 37, 1-8. [CrossRef]

14. Maree, J.G. Innovating Counselling for Self- and Career Construction: Connecting Conscious Knowledge with Subconscious Insight; Springer: New York, NY, USA, 2020.

15. Beerman, K.M.; Schultz, R.A.; Weber, C.L. Lack of awareness and emphasis in preservice teacher training: Preconceived beliefs about the gifted and talented. Gift. Child Today 2012, 35, 18-26. [CrossRef]

16. Gati, I.; Kulcsár, V. Making better career decisions: From challenges to opportunities. J. Vocat. Behav. 2021, 126, 103545. [CrossRef]

17. Gati, I.; Asher, I. Prescreening, in-depth exploration, and choice: From decision theory to career counseling practice. Career Dev. Q. 2001, 50, 140-157. [CrossRef]

18. Kelly, K.R.; Lee, W.C. Mapping the domain of career decision problems. J. Vocat. Behav. 2002, 61, 302-326. [CrossRef]

19. Marcia, J.E. Development and validation of ego identity status. J. Pers. Soc. Psychol. 1996, 3, 551. [CrossRef] [PubMed]

20. Marcia, J.E. Identity in Adolescence. In Handbook of Adolescent Psychology; Adelson, J., Ed.; Wiley: New York, NY, USA, 1980; pp. $159-187$.

21. Staunton, T. Mark Savickas and Life Design-Theories Every Careers Adviser Should Know. 2015. Available online: https: // runninginaforest.wordpress.com/2015/03/08/marksavickasandlifedesigntheorieseverycareersadvisershouldknow/ (accessed on 11 April 2021).

22. Savickas, M.L. Life Designing: A Paradigm for Career Construction. In Proceedings of the Keynote read at the 2nd Biennial African Congress of Career Practitioners, Pretoria, SA, USA, 19 March 2021.

23. Savickas, M.L. Career counselling paradigms: Guiding, developing, and designing. In The APA Handbook of Career Intervention; Hartung, P., Savickas, M.L., Walsh, W., Eds.; APA Books: Washington, DC, USA, 2015; Volume 1, pp. 129-143.

24. Maree, J.G. The psychosocial development theory of Erik Erikson: Critical overview. Early Child Dev. Care 2021, 191, 1107-1121. [CrossRef]

25. Chen, C.P.; Wong, J. Career counseling for gifted students. Aust. J. Career Dev. 2013, 22, 121-129. [CrossRef]

26. Rudolph, C.W.; Lavigne, K.N.; Zacher, H. Career adaptability: A meta-analysis of relationships with measures of adaptivity, adapting responses, and adaptation results. J. Vocat. Behav. 2017, 98, 17-34. [CrossRef]

27. Savickas, M.L.; Nota, L.; Rossier, J.; Dauwalder, J.-P.; Duarte, M.E.; Guichard, J.; Soresi, S.; Van Esbroeck, R.; Van Vianen, A.E.M. Life Designing: A paradigm for career construction in the 21th century. J. Vocat. Behav. 2009, 75, 239-250. [CrossRef]

28. Savickas, M.L. Career counselling in the post-modern era. J. Cogn. Psychother. An Int. Q. 1993, 42, 205-215. [CrossRef]

29. Savickas, M.L. Interactive Workshop on Life Design Counselling. In Proceedings of the XXXIXth International Congress of Psychology, Berlin, Germany; 2008.

30. Winnicott, D.W. The Child, the Family and the Outside World; Perseus: Cambridge, MA, USA, 1964.

31. Christison, M.-A.; Murray, D.E. An overview of multilingual learners' literacy needs for the 21st century. In Handbook of Research on Cultivating Literacy in Diverse and Multilingual Classrooms; Neokleous, G., Krulatz, A., Farrelly, R., Eds.; IGI Global: Hershey, PA, USA, 2020; pp. 1-21.

32. Hartung, P.J. Career Construction Counseling. In Psychology of Career Counseling: New Challenges for a New Era; Di Fabio, A., Maree, J.G., Eds.; Nova Science: New York, NY, USA, 2013; pp. 15-28.

33. Blustein, D.L.; Erby, W.; Meerkins, T.; Soldz, I.; Ezema, G.N. A critical exploration of assumptions underlying STEM career development. J. Career Dev. 2020, 40, 40-67. [CrossRef]

34. Hartung, P.J. Life design in childhood: Antecedents and advancement. In Handbook of Life Design: From Practice to Theory, and from Theory to Practice; Nota, L., Rossier, J., Eds.; Hogrefe: Göttingen, GE, USA, 2015; pp. 89-101.

35. McAdams, D.P. The psychological self as actor, agent, and author. Perspect. Psychol. Sci. 2013, 8, 272-295. [CrossRef]

36. Hall, A.S.; Kelly, K.K. Identity and Career Development in Gifted Students. In The Handbook of Secondary Education; Dixon, F.A., Moon, S.M., Eds.; Prufrock Press: Waco, TX, USA, 2014; pp. 352-364.

37. Maree, J.G.; Taylor, N. Development of the Maree Career Matrix: A new interest inventory. S. Afr. J. Psychol. 2016, 46, 462-476. [CrossRef]

38. Parsons, F. Choosing a Vocation; Houghton Mifflin: Boston, MA, USA, 1909.

39. Erikson, E.H. Identity, Youth, and Crisis; Norton: London, UK, 1968.

40. Mitchell, L.K.; Krumboltz, J.D. Social learning approach to career decision-making: Krumboltz's theory. In Career Choice and Development: Applying Contemporary Theories to Practice, 2nd ed.; Brown, D., Brooks, D., Associates, L., Eds.; Jossey Bass: San Francisco, CA, USA, 1990; pp. 145-196.

41. Owen, K.; Vosloo, H.N. Differential Aptitude Tests Form S; HSRC: Pretoria, SA, USA, 2000.

42. Maree, J.G. The Career Interest Profile; Version 6; JvR Psychometrics: Randburg, SA, USA, 2017. 
43. Maree, J.G.; Sommerville, J. Development of a post-modern career interest questionnaire. J. Psychol. Afr. 2008, 17, 125-130. [CrossRef]

44. Maree, J.G. Counselling for Career Construction: Connecting Life Themes to Construct Life Portraits. Turning Pain into Hope; Sense: Rotterdam, NL, USA, 2013.

45. Yin, R.K. Qualitative Research from Start to Finish; Guildford Press: New York, NY, USA, 2011.

46. Janesick, V.J. The Choreography of Qualitative Research. In Handbook of Qualitative Research, 2nd ed.; Denzin, N.K., Lincoln, Y.S., Eds.; Sage: London, UK, 2013; pp. 390-396.

47. Richardson, L. New writing practices in qualitative research. Sociol. Sport. J. 2000, 17, 5-20. [CrossRef]

48. Braun, V.; Clarke, V. Using thematic analysis in psychology. Qual. Res. Psychol. 2006, 3, 77-101. [CrossRef]

49. Hill, C.E.; Knox, S.; Thompson, B.J.; Williams, E.N.; Hess, S.A.; Ladany, N. Consensual qualitative research: An update. J. Couns. Psychol. 2005, 52, 196-205. [CrossRef]

50. Tonkin-Crine, S.; Anthierens, S.; Hood, K.; Yardley, L.; Cals, J.W.L.; Francis, N.A.; Coenen, S.; van der Gelden, A.W.; GodyckiCwirko, M.; Llor, C.; et al. Discrepancies between qualitative and quantitative evaluation of randomised controlled trial results: Achieving clarity through mixed methods triangulation. Implement. Sci. 2015, 11, 66. [CrossRef]

51. Hay-Smith, E.J.C.; Brown, M.; Anderson, L.; Treharne, G.J. Once a clinician, always a clinician: A systematic review to develop a typology of clinician-researcher dual-role experiences in health research with patient-participants. Med. Res. Methodol. 2016, 16, 1-17. [CrossRef]

52. Kewley, E.P. The Dual Role of Psychologist-Researcher: Using Psychological Assessments for Research Purposes; University of Lethbridge, Faculty of Education: Leithbridge, CN, USA, 2006.

53. Sieck, B.C. Obtaining clinical writing informed consent versus using client disguise and recommendations for practice. Psychotherapy 2012, 49, 3-11. [CrossRef]

54. Wood, S.M.; Klose Smith, S.; Duys, D.K. Career counselling and the gifted individual. In APA Handbook of Giftedness and Talent; Pfeiffer, S., Ed.; American Psychological Association: New York, NY, USA, 2018; pp. 629-644.

55. Plucker, J.; Rinn, A. From Giftedness to Gifted Education: Reflecting Theory in Practice; Prufrock Press: Waco, TX, USA, 2017.

56. Ricoeur, P. Time and Narrative; University of Chicago Press: Chicago, IL, USA, 1988; Volume 3.

57. Duffy, R.D.; Dik, B.J. Beyond the self: External influences in the career development process. Career Dev. Q. 2009, 58, 29-43. [CrossRef]

58. Harlow, T.B. Helping Gifted Kids Thrive; Guidingbright: Steamboat Springs, CO, USA, 2018. Available online: https: / / guidingbright.lpages.co/expertebook (accessed on 23 May 2021).

59. Maree, J.G. Career construction counseling: A thematic analysis of outcomes for four clients. J. Vocat. Behav. 2015, 86, 1-9. [CrossRef]

60. Miller, M.J. Brief reflections on a career in careers. J. Employ. Couns. 2009, 46, 47-48. [CrossRef]

61. Sharf, R.S. Applying Career Development Theory to Counseling, 6th ed.; Brooks/Cole: Pacific Grove, CA, USA, 2013.

62. Bar-On, R. The relationship between emotional intelligence and giftedness. Gift. Educ. Internat. 2007, 23, 136-150. [CrossRef]

63. Drolet, J.-L. Transcending death during early adulthood: Symbolic immortality, death anxiety, and purpose in life. J. Clin. Psychol. 1990, 46, 148-160. [CrossRef]

64. Huta, V.; Zuroff, D.C. Examining mediators of the link between generativity and well-being. J. Adult Dev. 2007, 14, 47-52. [CrossRef]

65. Pfeiffer, S.I. Essentials of Gifted Assessment; Wiley: New York, NY, USA, 2015. 